\title{
Erratum: Free-standing supramolecular hydrogel objects by reaction-diffusion
}

Matija Lovrak, Wouter E.J. Hendriksen, Chandan Maity, Serhii Mytnyk, Volkert van Steijn, Rienk Eelkema \& Jan H. van Esch

Nature Communications 8:15137 doi: 10.1038/ncomms15317 (2017); Published 5 Jun 2017; Updated 30 Jun 2017

In the original HTML version of this Article, which was published on 5 June 2017, the publication date was incorrectly given as 5 July 2017. This has now been corrected in the HTML; the PDF version of the paper was correct from the time of publication.

Open Access This article is licensed under a Creative Commons Attribution 4.0 International License, which permits use, sharing, adaptation, distribution and reproduction in any medium or format, as long as you give appropriate credit to the original author(s) and the source, provide a link to the Creative Commons license, and indicate if changes were made. The images or other third party material in this article are included in the article's Creative Commons license, unless indicated otherwise in a credit line to the material. If material is not included in the article's Creative Commons license and your intended use is not permitted by statutory regulation or exceeds the permitted use, you will need to obtain permission directly from the copyright holder. To view a copy of this license, visit http://creativecommons.org/licenses/by/4.0/

(C) The Author(s) 2017
} 